\title{
Phytase Production from a Novel Klebsiella sp. on Wheat Bran for Animal Feed Digestion
}

\author{
Dilruba Akter ${ }^{a}$, Md. Murad Khan ${ }^{b}$, Md. Mahmuduzzaman Mian ${ }^{a}$, Shakila Nargis Khan ${ }^{a}$ and Md. Mozammel \\ $\mathrm{Hoq}^{a^{*}}$
}

\begin{abstract}
Background. The present study was aimed to isolate phytase producing bacteria and optimize the physicochemical parameters of their phytase production. Materials and methods. Four bacterial isolates (Phs4, Phs5, Phs6, and Phs8), based on clear zone formation on phytase screening medium, were selected and tested for finding out the highest phytase producing strain. The production of phytase was then optimized and its biochemical properties were determined to judge the applicability of phytase as a digestive aid in animal feed. Results. The 4 bacterial isolates (Phs4, Phs5, Phs6 and Phs8) were identified by morphological, cultural, biochemical and molecular characterization as Burkholderia cepacia, Escherichia coli, Klebsiella pneumoniae and Klebsiella sp. respectively. Of these isolates, Phs8 (Klebsiella sp.) was found to produce maximum phytase in shake culture in a basal medium containing Na-phytate at $37^{\circ} \mathrm{C}$ and $\mathrm{pH} 5.5$ after 72 hours of incubation. The omission of $\mathrm{Na}$-phytate from the medium almost completely abolished the phytase production capacity of the isolate and thus signified its important role as an inducer. Among the different complex carbon sources, viz., glucose, wheat bran, rice bran and chickpea, maximum phytase production (94 unit/ $\mathrm{ml}$ ) was obtained with wheat bran under comparable cultivation conditions. The phytase works best at a
\end{abstract}

\section{Significance | Economic production of bac-} terial phytase as a poultry feed supplement

*Correspondence: Md. Mozammel Hoq, Professor, Department of Microbiology, University of Dhaka, Dhaka-1000, Bangladesh. Tel: 9661920-73/7734, +8801717083673,

E-mail: mhoq@du.ac.bd

Edited by Alamgir Rahman, PhD, North Carolina State University, NC, USA, and accepted by the Editorial Board May 23, 2018 (received for review March 3, 2018) temperature of $37^{\circ} \mathrm{C}$ and $\mathrm{pH}$ of 4.0 with a wide temperature stability (more than $80 \%$ activity up to $80^{\circ} \mathrm{C}$ ) and wide $\mathrm{pH}$ stability (more than $80 \%$ activity within a range of $\mathrm{pH} 3-8)$. Although $\mathrm{Zn}^{2+}, \mathrm{Co}^{2+}$, and $\mathrm{Fe}^{2+}$ slightly increased the phytase activity $\mathrm{Cu}^{2+}$ and $\mathrm{Mg}^{2+}$ strongly inhibited the enzyme. Conclusion. The present findings will be very useful for the development of a bioprocess of the enzyme for its large-scale production at the pilot and finally at the commercial level.

Keywords: Phytase; animal feed; Klebsiella sp.; enzyme activity.

Abbreviations: PSM, phytase screening medium; PPM, phytase production medium; LB, Luria-Bertani; RPM, rotation per minute; PCR, polymerase chain reaction; dNTPs, deoxyribonucleotides; EDTA, ethylenediaminetetraacetic acid; EtBr, ethidium bromide; KIA, Kligler iron agar; MIU, motility indole urease test; VP, Voges-Proskauer test.

\section{Introduction}

Phosphorus is one of the most important minerals in animal nutrition and essential constituent of life (Hegsted 1968; Maathuis, 2009). Although phosphorus can be obtained from many sources, phytic acid is the major storage form typically found in cereals, legumes and oil seeds- the main components of animal feed. In fact, most of plant origin food contain $50-80 \%$ of their phosphorus in the form of phytic acid (Harland \& Morris, 1995). Phytic acid has widely been known for its anti-nutritional activities which chelate the micronutrients like calcium, magnesium, manganese, sodium, zinc, iron etc., certain proteins and few enzymes and prevents their bioavailability for monogastric animals as they lack the enzyme needed for digestion of phytic acid (Badone, Amelotti, Cassani, \& Pilu, 2012; Gupta, Gangoliya,

\section{Author Affiliation:}

a Department of Microbiology, University of Dhaka, Dhaka-1000, Bangladesh.

${ }^{b}$ Department of Microbiology, Jagannath University, Dhaka-1100, Bangladesh.

Please cite this article:

Akter D, Khan MM, Mian MM, Khan SN, Hoq MM (2018). Phytase Production from a Novel Klebsiella sp. on Wheat Bran for Animal Feed Digestion. Microbial Bioactives, 1(1), 014-021 
\& Singh, 2015; J Kerovuo \& Tynkkynen, 2000; Selle, Cowieson, Cowieson, \& Ravindran, 2012).

Phytases are a special class of phosphatases that catalyze the formation of less phosphorylated myo-inositol derivatives and inorganic phosphate by sequential hydrolysis of myo-inositol$(1,2,3,4,5,6)$-hexakisphosphate or phytic acid (InsP6) (Haros, Bielecka, Honke, \& Sanz, 2007). Monogastric animals including poultry lack adequate level of phytase enzyme in their digestive tracts and thus can't hydrolyze the phytic acid present in the feed (Singh, Kunze, \& Satyanarayana, 2011). As a result, almost $70 \%$ of phosphate is released in their excreta as manure and subsequent runoff can cause severe eutrophication that may become a thread to the aquatic lives (Jorquera, MARTíNEZ, Maruyama, Marschner, \& de la Luz Mora, 2008). Therefore, inorganic phosphate is supplemented with the feed to ensure the proper growth of the animals. However, this doesn't diminish the anti-nutritive value of the phytic acid present in the feed and also increase the overall cost of feed production. Thus, as alternative, supplementation of phytase in animal feed has long been practiced and found effective both to enhance the nutritional value of plant material by liberating the phosphate from proper digestion of phytic acid and reduce the phosphate pollution (Mullaney \& Ullah, 2003; Musapuor, Afsharmanesh, \& Shahrbabak, 2006). Microbial phytase is considered most promising for commercial production, though phytase has also been derived from several other sources like plant and animals (Gontia, Tantwai, Rajput, \& Tiwari, 2012; Haros et al., 2007; Hill, Kysela, \& Elimelech, 2007; Pandey, Szakacs, Soccol, Rodriguez-Leon, \& Soccol, 2001). Most of the scientific work has been done on those originating from filamentous fungi such as Aspergillus niger (Soni \& Khire, 2007), Rhizopus oligosporus and Cladosporium species (Quan, Tian, Fan, \& Kikuchi, 2004). Other than these species, phytase from bacterial sources such as Escherichia coli (Rt Greiner, Konietzny, \& Jany, 1993), Pseudomonas sp. (Cho et al., 2003), Klebsiella sp. (Ralf Greiner \& Carlsson, 2006) and Bacillus sp. (Janne Kerovuo, Lauraeus, Nurminen, Kalkkinen, \& Apajalahti, 1998) were also identified. Recent studies suggest that bacterial phytases have a high potential for use as feed additives due to their biochemical properties like stability at low $\mathrm{pH}$ and high temperature, increase affinity for phytate etc. (Elkhalil, Männer, Borriss, \& Simon, 2007; Jones, 2013).

The present study is aimed to isolate the phytase producing bacteria from different sources like paddy field, wheat field, corn field, poultry soil, poultry feces and rhizosphere soil and optimize the cultural conditions of the most potential isolate, i.e., Klebsiella sp. for enhanced production of phytase.

\section{Materials and Methods}

\subsection{Screening and identification of phytase producing bacteria}

Soil samples were collected from different prominent habitats of phytase producing bacteria such as wheat field, corn field, rice field, poultry farm and rhizosphere soil. From the each collected sample, $1 \mathrm{~g}$ of soil was suspended in $0.85 \%$ saline and diluted. Diluted samples $\left(10^{3}\right.$ or $\left.10^{4}\right)$ were then spread onto the PSM plates (Glucose $15 \mathrm{~g} / \mathrm{L},\left(\mathrm{NH}_{4}\right)_{2} \mathrm{SO}_{4} 5 \mathrm{~g} / \mathrm{L}, \mathrm{KCl} 0.5 \mathrm{~g} / \mathrm{L}, \mathrm{MgSO}_{4} 0.1 \mathrm{~g} / \mathrm{L}, \mathrm{NaCl}$ $0.1 \mathrm{~g} / \mathrm{L}, \quad \mathrm{CaCl}_{2} .2 \mathrm{H}_{2} \mathrm{O} \quad 0.1 \mathrm{~g} / \mathrm{L}, \quad \mathrm{FeSO}_{4} 0.01 \mathrm{~g} / \mathrm{L}, \mathrm{MnSO}_{4} 0.01 \mathrm{~g} / \mathrm{L}$, $\mathrm{Na}-\mathrm{Phytate} 5 \mathrm{~g} / \mathrm{L}$, Agar $15 \mathrm{~g} / \mathrm{L}$ ) and incubated at $37^{\circ} \mathrm{C}$ for $1-4$ days and observed for the clear zones of hydrolysis around the colonies which gave an indication of extracellular phytase production (Bae, Yanke, Cheng, \& Selinger, 1999). Then selected colonies were grown in $50 \mathrm{ml}$ liquid medium (Phytase production mediumglucose $15.0 \mathrm{~g} / \mathrm{L}$, tryptone $1.0 \mathrm{~g} / \mathrm{L}, \mathrm{Na}$-phytate $1.0 \mathrm{~g} / \mathrm{L}, \mathrm{CaCl}_{2} 0.3 \mathrm{~g} / \mathrm{L}$, $\mathrm{MgSO}_{4} 0.5 \mathrm{~g} / \mathrm{L}, \mathrm{MnSO}_{4} 0.04 \mathrm{~g} / \mathrm{L}$, and $\mathrm{FeSO}_{4} 0.0025 \mathrm{~g} / \mathrm{L}$ at $\mathrm{pH} 6.5$ ) (Aziz et al., 2015). Isolates were first inoculated in LB broth for overnight and then re-inoculated (3\% inoculum) in the phytase production media. Culture was incubated at $37^{\circ} \mathrm{C}$ for $1-3$ days at $150 \mathrm{rpm}$. Crude enzyme was harvested by centrifugation at 6000 rpm for 10 minutes at $4^{\circ} \mathrm{C}$ and the clear supernatant was used as the source of extracellular phytases and for enzymatic assay. Bacterial isolates were subjected to a series of biochemical tests (Cappuccino \& Sherman, 2008) and 16s rDNA sequencing for identification.

For the molecular identification of the isolates, amplification of 16s rDNA conserved sequence (amplicon size $1465 \mathrm{bp}$ ) by PCR was done using 27 forward (5'-AGAGTTTGATCMTGGCTCAG-3') and 1492 reverse (5'-CGGTTACCTTGTTACGACTT-3') primers under standard conditions. The PCR reaction contain 10 $\mu \mathrm{l}$ master mix (Taq polymerase, dNTPs, $\mathrm{MgCl}_{2}, 10 \mathrm{X}$ buffer and PCR grade water), $7 \mu \mathrm{l}$ PCR grade water, $1 \mu \mathrm{l}$ of template and $1 \mu \mathrm{l}$ of each primer in $20 \mu \mathrm{l}$ reaction volume. The PCR products were checked by horizontal electrophoresis in 1.5\% agarose slab gel in Tris-borate EDTA (TBE) buffer and the EtBr stained DNA bands were then observed on a UV transilluminator (Gel Doc, BioRad, USA).

The purified PCR products were sequenced by chain termination method in DNA Solution Laboratory, Dhaka, Bangladesh. The partial 16S rDNA gene sequences of studied bacteria were then analyzed with nucleotide BLAST search in GenBank (NCBI) to generate a table of similar organisms for each test bacterium. FASTA format of the sequences obtained from these organisms were checked for multiple sequence alignment. The phylogenetic trees for each bacterium were generated using the Neighbor-Joining method (Saitou \& Nei, 1987). The percentage of replicate trees in which the associated taxa clustered together in the bootstrap test (1000 replicates) are shown next to the branches (Felsenstein, 1985). The tree is drawn to scale, with branch lengths in the same units as those of the evolutionary distances used to infer the phylogenetic tree. The evolutionary distances were computed using the Kimura 2-parameter method (Kimura, 1980) and are in the units of the number of base substitutions per site. The rate 
variation among sites was modeled with a gamma distribution (shape parameter $=0.05$ ). Evolutionary analyses were conducted in MEGA X (Kumar, Stecher, Li, Knyaz, \& Tamura, 2018).

\subsection{Enzymatic assay}

The phytase activity was determined by modified Bea et al. (Bae et al., 1999) method. $300 \mu$ l of the enzyme solution was incubated with $1.2 \mathrm{ml}$ of substrate solution $[0.2 \%(\mathrm{w} / \mathrm{v})$ sodium phytate (Sigma, St Louis, MO, USA) in $0.1 \mathrm{M}$ sodium acetate buffer, $\mathrm{pH}$ 5.0] for 30 minutes at $37^{\circ} \mathrm{C}$ and then $1.5 \mathrm{ml}$ of $10 \%(\mathrm{w} / \mathrm{v})$ trichloroacetic acid was added to stop the reaction. From this mixture, $1.5 \mathrm{ml}$ was transferred to a new test tube and mixed with $1.5 \mathrm{ml}$ ammonium molybdate ferrous sulfate mixture, which had been prepared by mixing 4 volumes of $1.5 \%(\mathrm{w} / \mathrm{v})$ ammonium molybdate (Merck, Germany) in 5.5\% sulfuric acid (Merck, Germany) with 1 volume of $2.7 \%(\mathrm{w} / \mathrm{v})$ ferrous sulfate solution. The inorganic phosphate, liberated from Na-phytate by the action of phytase, reacts with ammonium molybdate ferrous sulfate mixture to produce a colored compound phosphomolybdate which was measured spectrophotometrically at $700 \mathrm{~nm}$. One enzyme unit (IU) was defined as the amount of enzyme liberating $1 \mu \mathrm{mol}$ of inorganic phosphate in 1 minute under the assay conditions.

\subsection{Effect of different carbon sources on phytase produc- tion}

Effect of different carbon sources on phytase production was observed by preparing the production medium with different carbon source. Wheat bran, rice bran or chickpea $(1 \% \mathrm{w} / \mathrm{v})$ was used as carbon sole source as alternative to glucose $(0.3 \% \mathrm{w} / \mathrm{v})$ with the original basal medium. The flasks were incubated at $37^{\circ} \mathrm{C}$ at $150 \mathrm{rpm}$ for 72 hours. The phytase activity was measured at 24 hours of interval.

\subsection{Effect of Na-phytate concentrations on phytase production}

Two different concentrations of Na-phytate $(0.03 \mathrm{~g} / \mathrm{L}$ and $0.05 \mathrm{~g} / \mathrm{L}$ ) were used with wheat bran, as carbon source, and other mineral salts. Conical flasks with $50 \mathrm{ml}$ medium were inoculated with actively growing culture and were incubated at $37^{\circ} \mathrm{C}$ at 150 rpm for 72 hours.

\subsection{Effect of $\mathrm{pH}$ on phytase production}

The effect of $\mathrm{pH}$ in culture medium containing wheat bran (best carbon source) on the production of phytase was studied at $\mathrm{pH}$ value of $4.5,5.0,5.5,6.0,6.5,7.0$ and 7.5. $\mathrm{pH}$ was adjusted in production medium by adding $0.1 \mathrm{M} \mathrm{NaOH} / 0.1 \mathrm{M} \mathrm{HCl}$. The culture medium in the flasks were inoculated with actively growing culture and incubated at $37^{\circ} \mathrm{C}$ at $150 \mathrm{rpm}$ for 72 hours.

\subsection{Effect of temperatures on phytase production}

The production of phytase was carried out with the different temperature at $30,37,40,45$ and $50^{\circ} \mathrm{C}$ by keeping the agitator (revolutionary speed) at $150 \mathrm{rpm}$, and $\mathrm{pH}$ at 5.5 for 72 hours. The crude enzyme extract was separated by centrifugation at 6,000 rpm for 10 minutes at $4^{\circ} \mathrm{C}$. The supernatant was then used to assay phytase activity.

\subsection{Biochemical characterization of phytase}

\section{Effect of temperature and $\mathrm{pH}$ on phytase assay}

The activity of crude enzyme was determined by incubating the enzyme with $0.2 \%(\mathrm{w} / \mathrm{v})$ Na-phytate as a substrate at various temperatures ranged from 25 to $55^{\circ} \mathrm{C}$ for 30 minutes and optimal $\mathrm{pH}$ of crude phytase was determined by incubating in different buffer solutions (Glycine-HCl buffer $\mathrm{pH} 2 \sim 3$, Na-acetate-acetate buffer $\mathrm{pH} 4 \sim 6$ and Tris- $\mathrm{HCl}, \mathrm{pH} 7.0 \sim 9 ;$ ) at $37^{\circ} \mathrm{C}$ for 30 minutes.

\section{Stability of enzyme at different $\mathrm{pH}$ and temperatures}

Stability of the enzyme was studied at different $\mathrm{pH}$ and temperatures by pre-incubation (with or without $5 \mathrm{mM} \mathrm{CaCl}_{2}$ ) with buffer. The enzyme was maintained at different $\mathrm{pH}(2 \sim 9)$ and different temperatures from 40 to $100^{\circ} \mathrm{C}$ in water bath for 1 hour. The residual phytase activity in the samples at different intervals was assayed using sodium phytate as substrate.

\section{Effect of various metal ions on phytase activity}

Impact of various metal ions $\left(\mathrm{Ca}^{2+}, \mathrm{Co}^{2+}, \mathrm{Cu}^{2+}, \mathrm{Mg}^{2+}, \mathrm{Fe}^{2+}, \mathrm{Na}^{+}\right.$ and $\mathrm{Zn}^{2+}$ ) was investigated by pre-incubating the phytase enzyme at room temperature in a specified ion ( $5 \mathrm{mM}$ final concentration) containing buffer solution. After 1 hour of incubation, substrate $(0.2 \% \mathrm{Na}$-phytate) was added and residual activity of the enzyme was measured under standard assay conditions (untreated enzyme was taken as control).

\subsection{Statistical analysis}

All enzymatic assay (Unit/ml) was carried out in triplicate and data presented as Mean \pm SD.

\section{Results}

Four phytase producing bacterial isolates were isolated from soil samples. Among them, Klebsiella sp. had revealed as the highest phytate hydrolyzer on wheat bran under comparable conditions employed. The effect of different carbon sources, temperatures and $\mathrm{pH}$ for maximum production of enzyme were investigated. The properties of crude enzyme were also characterized.

\subsection{Isolation and identification of the phytase producing bacteria}

Each soil sample was diluted suitably and plated on phytase screening medium. After 72 hours of incubation at $37^{\circ} \mathrm{C}$, nine isolates were selected based on the clear zone formed upon Na-phytate hydrolyzation around the colonies. Of them, four isolates (named as $\mathrm{Phs} 4$, Phs5, Phs6 and Phs8) were found producing larger clear zone $(1.4 \mathrm{~mm}, 1.1 \mathrm{~mm}, 1.6 \mathrm{~mm}$ and $2.5 \mathrm{~mm}$ ) and identified as Burkholderia cepacia, Escherichia coli, Klebsiella pneumoniae, and Klebsiella sp. respectively by microscopic, cultural and biochemical tests (Table 1) and 16S rDNA gene sequence analysis (result shown for Klebsiella sp. in Figure 1). Both solid and liquid screening processes were employed to deter- 
Table 1 | Summary of different biochemical tests.

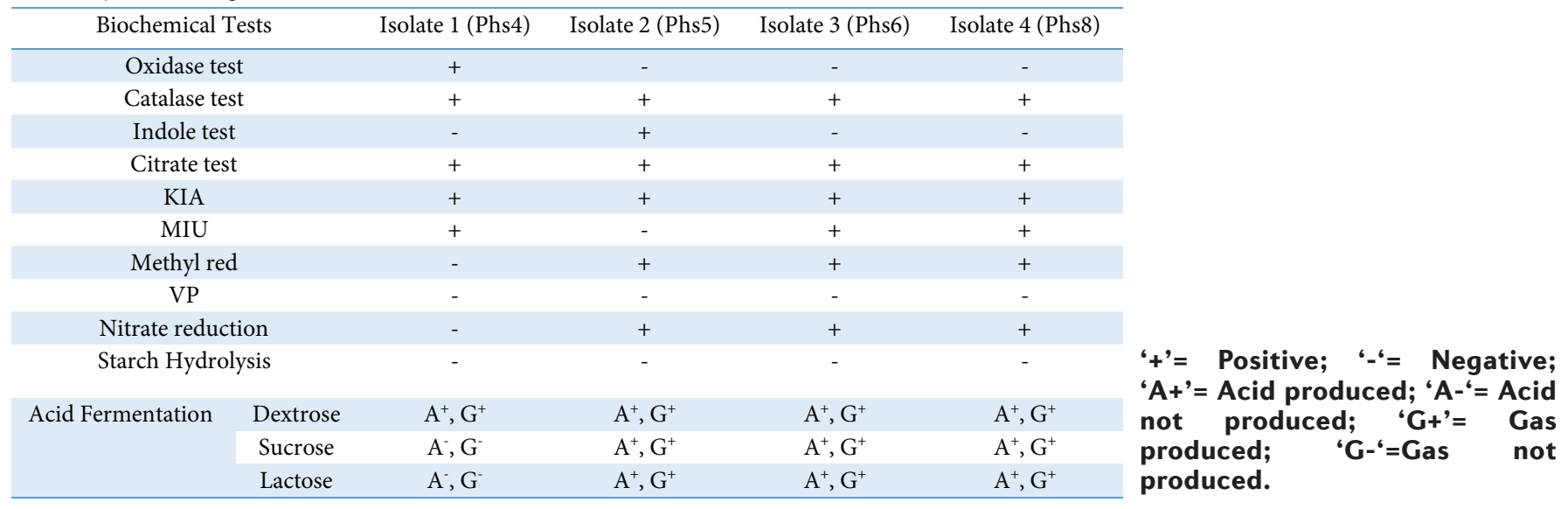

mine the ability of the isolated strains to produce phytase. Amon the four isolated bacterial strains, Klebsiella sp. was found to produce maximum phytase on phytase production medium and thus selected for further analysis (Figure 2).

\subsection{Effect of different carbon sources on phytase produc-} tion by Klebsiella sp.

Result showed that highest phytase activity (94 unit/ml) was found in medium containing wheat bran as a carbon source after 72 hours of incubation (Figure 3). Other two carbon sources, rice bran and chickpea, showed enzyme activity of 58 and 14 unit $/ \mathrm{ml}$ respectively. Whereas, $44 \mathrm{unit} / \mathrm{ml}$ activity was found using glucose as a carbon source. Hence, the following studies were done using basal medium containing wheat bran as a carbon source. On the other hand, ability of the Na-phytate as inducer of phytase production by the bacterium became prominent from the

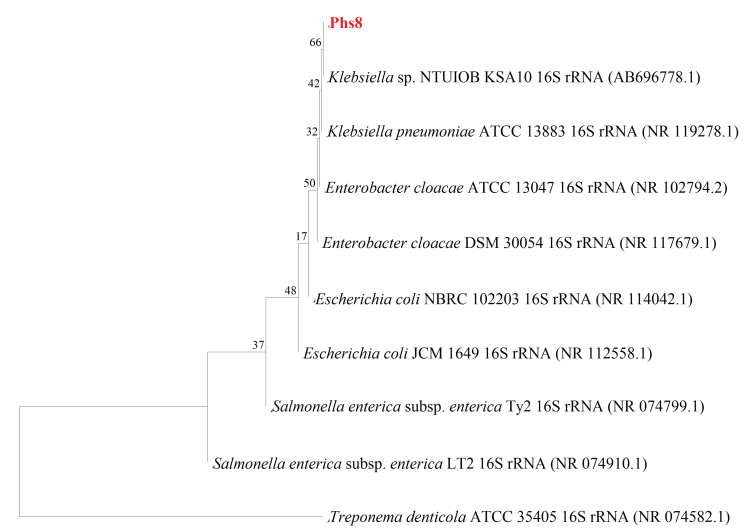

\section{Figure 1| Phylogenetic tree analysis of Phs8 isolate with aligned sequences.}

Klebsiella sp. was 5.5 after 72 hours of incubation at $37^{\circ} \mathrm{C}$ and 150 $\mathrm{rpm}$. The decrease in enzyme production was observed by both increasing and decreasing the $\mathrm{pH}$ value from 5.5. The relative enzyme activity was found at $\mathrm{pH} 4.5,5.0,5.5,6.0,6.5,7.0$ and 7.5 as $74,81,96,64,54$, and $44 \%$ as compared to the highest activity at $\mathrm{pH} 5.5$. Activity at $\mathrm{pH} 5.5$ was taken as $100 \%$.

\subsection{Effect of temperatures on phytase production}

fact that, the enzyme activity in all carbon sources was almost abolished without Na-phytate.

\subsection{Optimization of Na-phytate concentration for phytase production by Klebsiella sp.}

Two different concentrations of Na-phytate was used for phytase production in phytase production medium containing wheat bran as carbon source under different cultivation hours. Among them, $0.5 \% \mathrm{Na}$-phytate showed better activity (94 unit $/ \mathrm{ml}$ ) as compared that of $0.3 \%$ (32 unit $/ \mathrm{ml}$ ) after 72 hours of incubation (Figure 4). Further increase of Na-phytate might increase the enzyme activity but needs investigation.

\subsection{Effect of $\mathrm{pH}$ on phytase production}

Phytase production was assayed in a wide range of $\mathrm{pH}$ (from 4.5 to 7.5) to determine the effect of $\mathrm{pH}$ on the enzyme production. Figure 5 showed that the optimum $\mathrm{pH}$ of phytase production for
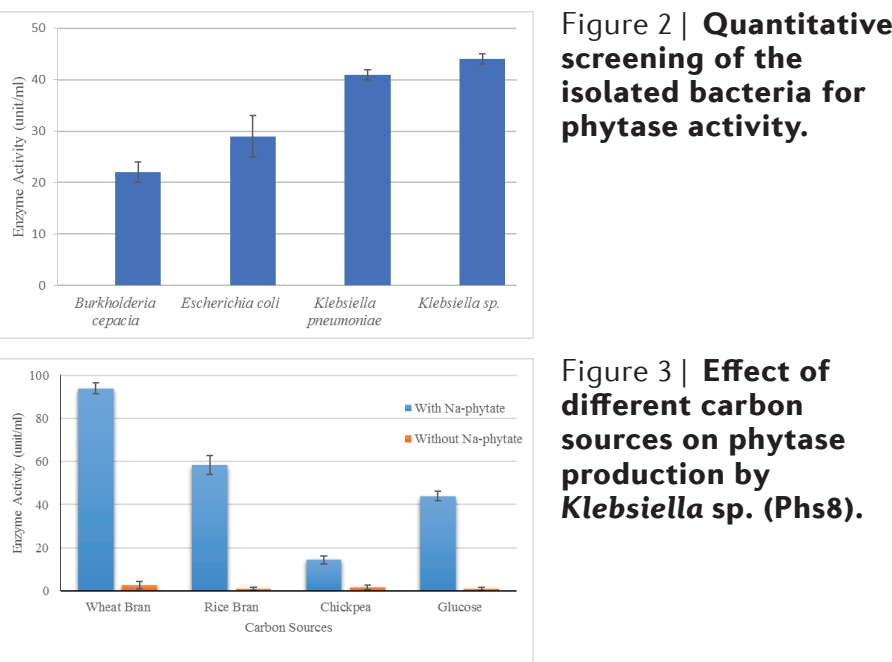

Figure 3 | Effect of different carbon sources on phytase production by Klebsiella sp. (Phs8).

The wheat bran with basal component medium was inoculated with $3 \%$ inoculum and incubated at various temperatures ranging from $30-50^{\circ} \mathrm{C}$ at $150 \mathrm{rpm}$ for 72 hours. It is evident from the results that maximum phytase production was observed at $37^{\circ} \mathrm{C}$ after 72 hours of incubation. As the temperature increased above $37^{\circ} \mathrm{C}$, the relative enzyme activity decreased gradually to 94,83 and $75 \%$ at 40,45 and $50^{\circ} \mathrm{C}$ respectively. Similar result found with 


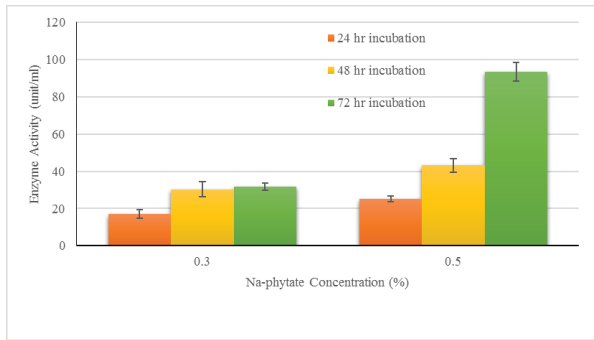

Figure 4| Optimization of Na-phytate concentrations for phytase production.

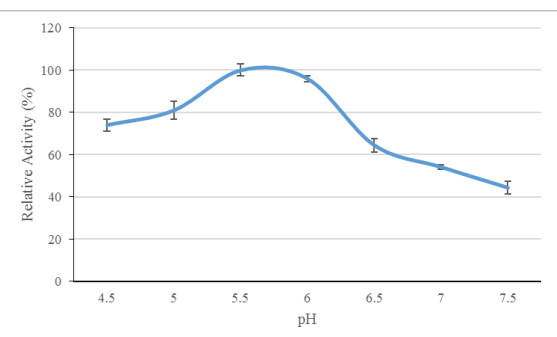

Figure 5 | Effect of $\mathbf{p H}$ on production of phytase by Klebsiella sp.

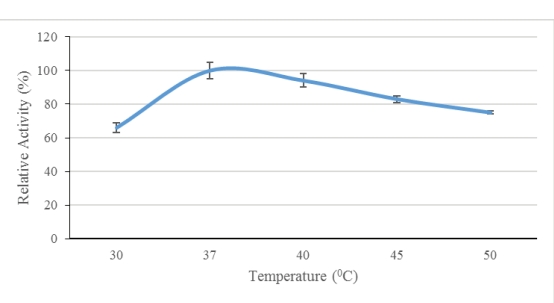

Figure 6 | Effect of temperatures on phytase production by Klebsiella sp.

decrease in temperature from the optimum value to $30^{\circ} \mathrm{C}$ with relative activity $66 \%$ (Figure 6 ). The enzyme activity at optimum temperature i.e., at $37^{\circ} \mathrm{C}$ was taken as $100 \%$.

\subsection{Biochemical characterization of phytase}

\section{Optimum temperature for phytase activity}

The phytase activities were assayed at different temperatures ranging from $25-55^{\circ} \mathrm{C}$ to examine the effect of temperature on its function. Enzyme activity increased within temperature range of $25-37^{\circ} \mathrm{C}$ and a maximum increase was found at $37^{\circ} \mathrm{C}$ for crude enzyme, then it started to decrease from $40^{\circ} \mathrm{C}$ to onward and became least at $55^{\circ} \mathrm{C}$ (Figure 7). The enzyme however retained $80 \%$ of its highest activity at $55^{\circ} \mathrm{C}$. The enzyme activity at optimum temperature was taken as $100 \%$.

Thermo-stability of the enzyme produced by Klebsiella sp.

Presence of $\mathrm{Ca}^{2+}$ ion may enhance the enzyme stability due to their ability to act as a co-factor for the enzyme. The reaction mixtures of crude enzyme were incubated at various temperatures ranging from $40-100^{\circ} \mathrm{C}$ for 1 hour in absence and presence of $5 \mathrm{mM}$ of $\mathrm{CaCl}_{2}$. After incubation, the residual activity was measured under standard assay conditions. Activity of control, without any temperature incubation, was taken as $100 \%$. Although at $40-80^{\circ} \mathrm{C}$ no or slight decrease in enzyme activity was found in absence of $\mathrm{CaCl}_{2}$ a marked decrease in activity was found with further increase in temperature from $90-100^{\circ} \mathrm{C}$ with residual activities as 77 and $20 \%$ respectively as compared to the control. Presence of $\mathrm{CaCl}_{2}$, however, resulted in non-significant higher residual activities at each respective temperature value (Figure 7).

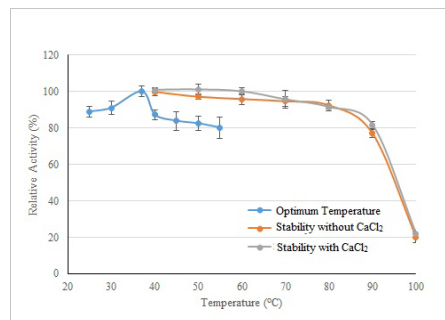

Figure 7| Optimum temperature and thermostability of phytase from Klebsiella sp.

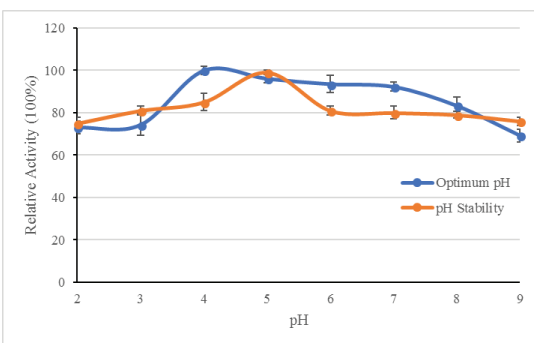

Figure 8| Optimum $\mathrm{pH}$ and $\mathrm{pH}$ stability of phytase from Klebsiella sp.

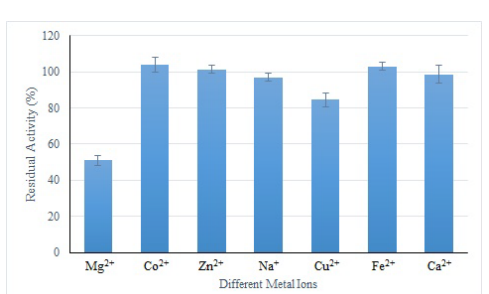

Figure 9 | Effect of different metal ions on enzyme activity.

\section{Optimum pH and stability of phytase activity}

A broad $\mathrm{pH}$ range of 2-9 was examined to study the effect of $\mathrm{pH}$ on the enzyme activity (Figure 8 ). The enzyme was found to be stable over broad $\mathrm{pH}$ range with optimum activity at $\mathrm{pH} 4$ which indicates the acidic nature of the enzyme. A decrease in the enzyme activity was found in further acidic $\mathrm{pH}$. On the other hand, a gradual but slight decrease in activity was found with increase in $\mathrm{pH}$ from 4.0 to $\mathrm{pH} 8.0$ suggesting a broad stability range ( 80 to $100 \%$ residual activity) of the enzyme. The stability of the enzyme on different $\mathrm{pH}$ was checked by incubating it at various buffers of $\mathrm{pH}$ range 2-9 for 1 hour. After incubation, the residual activity was assayed and the results revealed the maximum residual activity as $99 \%$ at $\mathrm{pH} 5.0$ as compared to the control and marked increase was found by increasing the $\mathrm{pH}$ from 2-5 with residual activities as $75,81,85$ and $99 \%$ of its original activity respectively. Whereas, marked drop was found at $\mathrm{pH}$ 6-9 as $81,80,79$ and $76 \%$ of its original activity, respectively (Figure 8). Such result indicated the stability of the phytase over wide $\mathrm{pH}$ range particularly in the range of $\mathrm{pH}$ 3-8.

\section{Effect of different metal ions on phytase activity}

The effect of various metal ions at $5 \mathrm{mM}$ final concentration was studied following pre-incubation with crude enzyme for 1 hour at room temperature and the residual activity was assayed. Most of the metal ions tested had a stimulatory effect like $\mathrm{Zn}^{2+}, \mathrm{Co}^{2+}$ and $\mathrm{Fe}^{2+}$ with relative activities of 101, 104 and 104\% respectively, whereas $\mathrm{Cu}^{2+}$ was found moderately inhibitory (85\%). 
$\mathrm{Ca}^{2+}(99 \%)$ and $\mathrm{Na}^{+}(97 \%)$ had almost no effect on the enzyme activity. While $\mathrm{Mg}^{2+}$ had exerted almost $50 \%$ inhibitory effect on enzyme as compared to the control (Figure 9).

\section{Discussion}

In the present study, samples were collected from habitat like paddy field, wheat field, corn field, poultry soil, poultry feces and rhizosphere soil, which are believed to be rich source of phytase producing bacteria, to isolate the phytate degrading bacteria. Although nine isolates, from 19 soil samples, were found to have phytase activity only four isolates showed significant results. These four isolates were named as Phs4, Phs5, Phs6 \& Phs8. The isolates Phs4, Phs5, Phs6, and Phs8 were identified as Burkholderia cepacia, Escherichia coli, Klebsiella pneumoniae and Klebsiella sp. respectively by morphological, cultural, biochemical characteristics, and 16s rDNA PCR followed by phylogenetic tree analysis. Among these four-bacterial strains, Klebsiella sp. (Phs8) was found to produce maximum enzyme activity (44 unit/ml) in phytase producing medium. Several researchers including Aziz et al., Wang et al., Escobin-Moopera et al., and Unno et al. found the phytase activity from similar bacteria in different studies (Aziz et al., 2015; Escobin-Mopera et al., 2012; Unno, Okubo, Wasaki, Shinano, \& Osaki, 2005; Wang et al., 2004).

For an organism, to grow and to produce desired metabolites there is the need of energy and physical support which provided by the substrates (Pandey et al., 2001; Spier et al., 2008). The primarily selected medium (PPM) was taken as a basal medium and different parameters of culture such as carbon source, temperature and $\mathrm{pH}$ were studied (Aziz et al., 2015). Several carbon sources including glucose, wheat bran, rice bran and chickpea were used in basal medium separately, keeping the other component unchanged, to check their ability in phytase production. Use of alternative carbon sources like wheat bran, rice bran and chickpea not only reduced the cost of production but also increased the enzyme activity, though not by all carbon sources. Particularly, the phytase activity with wheat bran was found more than two times higher than that of with glucose. This is due to the fact that wheat bran contain phytic acid (3-6\% of the dry weight) complexed with many minerals and serve as additional phytate source and thereby more phytase activity (Bilgiçli \& İbanoğlu, 2007). This study was in harmony with Mittal et al. (Mittal, Singh, Goyal, Yadav, \& Aggarwal, 2012) who found wheat bran and orange peel flour as the highest phytase producing carbon sources by Klebsiella sp. Addition of Na-phytate (purest form) have an inducing effect on production of phytase. The importance of Na-phytate became clear from the fact that, absence of Na-phytate from the basal medium nearly abolished the phytase activity for all carbon sources used in our experiment.

While the optimal temperature for production of phytases from various sources varies from 30 to $80^{\circ} \mathrm{C}$ (Wang et al., 2004), the optimum temperature of phytase production was observed at $37^{\circ} \mathrm{C}$ form Klebsiella sp. (isolate $\mathrm{Phs} 8$ ). The maximum production of phytase by Klebsiella sp. at $37^{\circ} \mathrm{C}$ temperature has also been reported by several other researchers (Aziz et al., 2015; Wang et al., 2004). Another most important factor is $\mathrm{pH}$ of medium for enzyme production. The maximum phytase production was observed at $\mathrm{pH}$ 5.5. And further increase in $\mathrm{pH}$ reduced the growth and enzyme production. Maximum phytase production by Klebsiella pneumoniae SCTb2 was reported at $\mathrm{pH} 6.0$ by Das et al. (Das, Bandyopadhyay, \& Sen, 2013).

The biochemical properties of Klebsiella sp. phytase have much similarities with other bacterial and fungal phytases. The cell free supernatant of culture has the phytase activity that exhibited temperature optima at $37^{\circ} \mathrm{C}$ (Wang et al., 2004) and stable at wide range (up to $80^{\circ} \mathrm{C}$ ) of temperature. Phytase from some other microbes has also been found to function best at $37^{\circ} \mathrm{C}$ (Aly, Tork, Al-Garni, \& Kabli, 2015; El-Toukhy, Youssef, \& Mikhail, 2013). As the main intended application of phytase is the digestive aid in animal feed, it needs to be thermotolerant, so that the enzyme can withstand high temperature during pelleting process of food especially for monogastric animals (Arpana et al., 2011). At least $80 \%$ residual activity of phytase was found over broad $\mathrm{pH}$ range ( $\mathrm{pH} 3-8$ ) with highest activity at $\mathrm{pH} 4.0$ which indicates its acidic nature. Thus, the temperature and $\mathrm{pH}$ stability profile of the Klebsiella sp. phytase, which is similar to the conditions in the stomach of monogastric animals, made this an ideal candidate to be used as digestive aid in the animal feed of monogastric animals (Elkhalil et al., 2007; Escobin-Mopera et al., 2012; Sajidan et al., 2004). The catalytic activity of the phytase was not significantly affected by $\mathrm{Ca}^{2+}$ and $\mathrm{Na}^{+}$at $5 \mathrm{mM}$ concentration. This implied that even in the presence of $\mathrm{Ca}^{2+}$ ion or Ca-phytate complex, the phytase retained its almost full activity (99\%) (Escobin-Mopera et al., 2012). Other divalent cations like $\mathrm{Zn}^{2+}, \mathrm{Co}^{2+}$ and $\mathrm{Fe}^{2+}$ had a stimulatory effect on phytase. Phytase from Klebsiella pneumoniae subsp. pneumoniae XY-5 was found to be stimulated in presence of $\mathrm{Zn}^{2+}$ and $\mathrm{Co}^{2+}$ (Wang et al., 2004). On the other hand, $\mathrm{Cu}^{2+}$ showed moderate and $\mathrm{Mg}^{2+}$ showed strong inhibition profile to Klebsiella sp. phytase with reduction of $15 \%$ and $50 \%$ of the enzyme's initial activity respectively (Wang et al., 2004). Bacterial phytase, from Klebsiella sp. and as well from other bacterial species, was found to be strongly inhibited by $\mathrm{Mg}^{2+}$ (Escobin-Mopera et al., 2012; Hong, Chu, \& Chung, 2011; Kalsi, Singh, Dhaliwal, \& Kumar, 2016; Zhang et al., 2011).

\section{Conclusion}

Among the different environmental isolates, Klebsiella sp. (Phs8) exhibited the highest potentiality to produce the phytase enzyme. Based on the results, it has been found that Klebsiella sp. (Phs8) was able to enhance phytase production in cultures medium containing wheat bran as the carbon source, thus making the 
production process cheaper. In addition, the acido-thermo-stability nature of the enzyme implied its potential applicability in feed industry as a digestive aid.

\section{Acknowledgement}

We do acknowledge the partial financial support of Phenix Group, Bangladesh for encouraging this research work.

\section{Competing financial interest}

The author(s) declare no competing financial interests.

\section{Author contributions}

DA designed and performed the experiments, MMK prepared the draft and final version of the manuscript, MMM collected the samples, SNK and MMH supervised the whole work and critically reviewed the manuscript.

\section{References}

Aly, M. M., Tork, S., Al-Garni, S. M., \& Kabli, S. A. (2015). Production and Characterization of Phytase from Streptomyces luteogriseus R10 Isolated from Decaying Wood Samples. International Journal of Agriculture and Biology, 17(3), 515-522. doi:http://dx.doi.org/10.17957/ijab/17.3.14.453

Arpana, M., Gulab, S., Varsha, G., Anita, Y., KamalRai, A., SanjeevKumar, G., \& NeerajKumar, A. (2011). Isolation and biochemical characterization of acido-thermophilic extracellular phytase producing bacterial strain for potential application in poultry feed. Jundishapur Journal of Microbiology, 2011(4), 273-282.

Aziz, G., Nawaz, M., Anjum, A., Yaqub, T., Nazir, J., Khan, S., \& Aziz, K. (2015). Isolation and characterization of phytase producing bacterial isolates from soil. Journal of Animal \& Plant Sciences, 25(3), 771-776

Badone, F. C., Amelotti, M., Cassani, E., \& Pilu, R. (2012). Study of low phytic acid1-7 (Ipa1-7), a new ZmMRP4 mutation in maize. Journal of Heredity, 103(4), 598-605. doi:http://dx.doi.org/10.1093/jhered/ess014

Bae, H., Yanke, L., Cheng, K.-J., \& Selinger, L. (1999). A novel staining method for detecting phytase activity. Journal of Microbiological Methods, 39(1), 17-22. doi:http://dx.doi.org/10.1016/s0167-7012(99)00096-2

Bilgiçli, N., \& Ibanoğlu, Ş. (2007). Effect of wheat germ and wheat bran on the fermentation activity, phytic acid content and colour of tarhana, a wheat flour-yoghurt mixture. Journal of Food Engineering, 78(2), 681-686. doi:https://doi.org/10.1016/j.jfoodeng.2005.11.012

Cappuccino, J. G., \& Sherman, N. (2008). Microbiology: A Laboratory Manual (Vol. 9): Pearson/Benjamin Cummings Boston, MA.

Cho, J. S., Lee, C. W., Kang, S. H., Lee, J. C., Bok, J. D., Moon, Y. S., . . Choi, Y. J. (2003). Purification and characterization of a phytase from Pseudomonas syringae MOK1. Current Microbiology, 47(4), 0290-0294. doi:http://dx. doi.org/10.1007/s00284-002-3966-4

Das, K., Bandyopadhyay, D., \& Sen, S. K. (2013). Optimization of fermentation conditions for phytase production by the novel isolate Klebsiella sp. The Bioscan, 8(4), 1315-1320.

El-Toukhy, N. M., Youssef, A. S., \& Mikhail, M. G. (2013). Isolation, purification and characterization of phytase from Bacillus subtilis MJA. African Journal of Biotechnology, 12(20), 2957-2967.

Elkhalil, E., Männer, K., Borriss, R., \& Simon, O. (2007). In vitro and in vivo characteristics of bacterial phytases and their efficacy in broiler chickens. British Poultry Science, 48(1), 64-70. doi:http://dx.doi.org/10.1080/00071660601148195

Escobin-Mopera, L., Ohtani, M., Sekiguchi, S., Sone, T., Abe, A., Tanaka, M., . . Asano, K. (2012). Purification and characterization of phytase from Klebsiella pneumoniae 9-3B. Journal of Bioscience and Bioengineering, 113(5), 562-567. doi:http://dx.doi.org/10.1016/j.jbiosc.2011.12.010

Felsenstein, J. (1985). Confidence limits on phylogenies: an approach using the

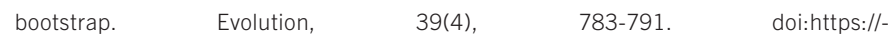
doi.org/10.1111/j.1558-5646.1985.tb00420.x

Gontia, I., Tantwai, K., Rajput, L. P. S., \& Tiwari, S. (2012). Transgenic plants expressing phytase gene of microbial origin and their prospective application as feed. Food Technology and Biotechnology, 50(1), 3.

Greiner, R., \& Carlsson, N.-G. (2006). Myo-Inositol phosphate isomers generated by the action of a phytate-degrading enzyme from Klebsiella terrigena on phytate. Canadian Journal of Microbiology, 52(8), 759-768. doi:http://dx.doi.org/10.1139/w06-028

Greiner, R., Konietzny, U., \& Jany, K.-D. (1993). Purification and characterization of two phytases from Escherichia coli. Archives of Biochemistry and Biophysics, 303(1), 107-113. doi:http://dx.doi.org/10.1006/abbi.1993.1261

Gupta, R. K., Gangoliya, S. S., \& Singh, N. K. (2015). Reduction of phytic acid and enhancement of bioavailable micronutrients in food grains. Journal of Food Science and Technology, 52(2), 676-684. doi:http://dx.doi.org/10.1007/s13197-013-0978-y Harland, B. F., \& Morris, E. R. (1995). Phytate: a good or a bad food component? Nutrition Research, 15(5), 733-754. doi:http://dx.doi.org/10.1016/0271-5317(95)00040-p

Haros, M., Bielecka, M., Honke, J., \& Sanz, Y. (2007). Myo-inositol hexakisphosphate degradation by Bifidobacterium infantis ATCC 15697. International Journal of Food Microbiology, 117(1), 76-84. doi:http://dx.doi.org/10.1016/j.ijfoodmicro.2007.02.021 Hegsted, D. (1968). Present knowledge of calcium, phosphorus, and magnesium. $\begin{array}{llll}\text { Nutrition } & \text { Reviews, } & \text { 26(3), } & \text { 65-70. }\end{array}$ doi.org/10.1111/j.1753-4887.1968.tb00862.x

Hill, J. E., Kysela, D., \& Elimelech, M. (2007). Isolation and assessment of phytate-hydrolysing bacteria from the DelMarVa Peninsula. Environmental Microbiology, 9(12), 3100-3107. doi:http://dx.doi.org/10.1111/j.1462-2920.2007.01420.x

Hong, S. W., Chu, I. H., \& Chung, K. S. (2011). Purification and biochemical characterization of thermostable phytase from newly isolated Bacillus subtilis CF92. Journal of the Korean Society for Applied Biological Chemistry, 54(1), 89-94. doi:http://dx.doi.org/10.3839/jksabc.2011.012

Jones, G. (2013). How to select the best phytase for your feed formulation. Retrieved from https://www.wattagnet.com/articles/17645-how-to-select-the-best-phytase-for-your-feed-formulation

Jorquera, M., MARTíNEZ, O., Maruyama, F., Marschner, P., \& de la Luz Mora, M. (2008). Current and future biotechnological applications of bacterial phytases and phytase-producing bacteria. Microbes and Environments, 23(3), 182-191. doi:http://dx.doi.org/10.1264/jsme2.23.182

Kalsi, H. K., Singh, R., Dhaliwal, H. S., \& Kumar, V. (2016). Phytases from Enterobacter and Serratia species with desirable characteristics for food and feed applications. 3 
Bacillus subtilis. Applied and Environmental Microbiology, 64(6), 2079-2085

Kerovuo, J., \& Tynkkynen, S. (2000). Expression of Bacillus subtilis phytase in Lactobacillus plantarum 755. Letters in Applied Microbiology, 30(4), 325-329. doi:http://dx. doi.org/10.1046/j.1472-765x.2000.00660.x

Kimura, M. (1980). A simple method for estimating evolutionary rates of base substitutions through comparative studies of nucleotide sequences. Journal of Molecular Evolution, 16(2), 111-120. doi:https://doi.org/10.1007/BF01731581

Kumar, S., Stecher, G., Li, M., Knyaz, C., \& Tamura, K. (2018). MEGA X: Molecular Evolutionary Genetics Analysis across Computing Platforms. Molecular Biology and Evolution, 35(6), 1547-1549. doi:https://doi.org/10.1093/molbev/msy096

Maathuis, F. J. (2009). Physiological functions of mineral macronutrients. Current Opinion in Plant Biology, 12(3), 250-258. doi:http://dx. doi.org/10.1016/j.pbi.2009.04.003

Mittal, A., Singh, G., Goyal, V., Yadav, A., \& Aggarwal, N. K. (2012). Production of phytase by acido-thermophilic strain of Klebsiella sp. DB-3FJ711774. 1 using orange peel flour under submerged fermentation. Innovative Romanian Food Biotechnology, $10,18$.

Mullaney, E. J., \& Ullah, A. H. (2003). The term phytase comprises several different classes of enzymes. Biochemical and Biophysical Research Communications, 312(1) 179-184. doi:http://dx.doi.org/10.1016/j.bbrc.2003.09.176

Musapuor, A., Afsharmanesh, M., \& Shahrbabak, H. M. (2006). Use of microbial phytase for decrease of pollutant due to environmental poultry excreta phosphorus. International Journal of Agriculture and Biology, 8(1), 35-37.

Pandey, A., Szakacs, G., Soccol, C. R., Rodriguez-Leon, J. A., \& Soccol, V. T. (2001). Production, purification and properties of microbial phytases. Bioresource Technology, 77(3), 203-214. doi:http://dx.doi.org/10.1016/s0960-8524(00)00139-5

Quan, C.-S., Tian, W.-J., Fan, S.-D., \& Kikuchi, J.-I. (2004). Purification and properties of a low-molecular-weight phytase from Cladosporium sp. FP-1. Journal of Bioscience and Bioengineering, 97(4), 260-266. doi:http://dx. doi.org/10.1016/s1389-1723(04)70201-7

Saitou, N., \& Nei, M. (1987). The neighbor-joining method: a new method for reconstructing phylogenetic trees. Molecular Biology and Evolution, 4(4), 406-425. doi:https://doi.org/10.1093/oxfordjournals.molbev.a040454

Sajidan, A., Farouk, A., Greiner, R., Jungblut, P., Müller, E.-C., \& Borriss, R. (2004). Molecular and physiological characterisation of a 3-phytase from soil bacterium Klebsiella sp. ASR1. Applied Microbiology and Biotechnology, 65(1), 110-118. doi:http://dx.doi.org/10.1007/s00253-003-1530-1

Selle, P. H., Cowieson, A. J., Cowieson, N. P., \& Ravindran, V. (2012). Protein-phytate interactions in pig and poultry nutrition: a reappraisal. Nutrition Research Reviews, 25(1), 1-17. doi:http://dx.doi.org/10.1017/s0954422411000151

Singh, B., Kunze, G., \& Satyanarayana, T. (2011). Developments in biochemical aspects and biotechnological applications of microbial phytases. Biotechnology and Molecular Biology Reviews, 6(3), 69-87.

Soni, S. K., \& Khire, J. M. (2007). Production and partial characterization of two types of phytase from Aspergillus niger NCIM 563 under submerged fermentation conditions. World Journal of Microbiology and Biotechnology, 23(11), 1585-1593. doi:http://dx. doi.org/10.1007/s11274-007-9404-9

Spier, M. R., Greiner, R., Rodriguez-León, J. A., Woiciechowski, A. L., Pandey, A., Soccol, V. T., \& Soccol, C. R. (2008). Phytase production using citric pulp and other residues of the agroindustry in SSF by fungal isolates. Food Technology \& Biotechnolo- gy, 46(2), 178-182. doi:http://dx.doi.org/10.1080/00986445.2010.493115 Unno, Y., Okubo, K., Wasaki, J., Shinano, T., \& Osaki, M. (2005). Plant growth promotion abilities and microscale bacterial dynamics in the rhizosphere of Lupin analysed by phytate utilization ability. Environmental Microbiology, 7(3), 396-404. doi:http://dx.doi.org/10.1111/j.1462-2920.2004.00701.x

Wang, X., Upatham, S., Panbangred, W., Isarangkul, D., Summpunn, P., Wiyakrutta, S., \& Meevootisom, V. (2004). Purification, characterization, gene cloning and sequence analysis of a phytase from Klebsiella pneumoniae subsp. pneumoniae XY-5. Science Asia, 30, 383-390. doi:http://dx.doi.org/10.2306/scienceasia1513-1874.2004.30.383 Zhang, R., Yang, P., Huang, H., Shi, P., Yuan, T., \& Yao, B. (2011). Two types of phytases (histidine acid phytase and $\beta$-propeller phytase) in Serratia sp. TN49 from the gut of Batocera horsfieldi (Coleoptera) larvae. Current Microbiology, 63(5), 408. doi:http://dx.doi.org/10.1007/s00284-011-9995-0
Submit your next manuscript to Microbial Bioactives published by EMAN Research

- Convenient online submission

- Thorough peer review

- No space constraints or color figure charges

- Immediate publication on acceptance

- Inclusion in Australian National Libraray and Google Scholar

- Both Open (80-100\% subsidized APC by ER) \& non-open access option 